\title{
KAJIAN PENGARUH SITU TERHADAP RESPON HIDROLOGI DI DAS PESANGGRAHAN MENGGUNAKAN MODEL HEC-HMS
}

\section{Study of Reservoir Effect on Hydrological Response of Pesanggrahan Watershed using HEC-HMS Model}

\author{
Selamet Kusdaryanto1), Dwi Putro Tejo Baskoro2), Suria Darma Tarigan²)* \\ 1)Alumni Program Studi Pengelolaan Daerah Aliran Sungai, Depertemen Ilmu Tanah dan Sumber Daya Lahan, \\ Fakultas Pertanian IPB, Jl Meranti Kampus IPB Dramaga Bogor 16680. \\ 2)Departemen Ilmu Tanah dan Sumberdaya Lahan, Fakultas Pertanian IPB, J1 Meranti Kampus IPB Dramaga Bogor \\ 16680.
}

\begin{abstract}
Pesanggrahan river with total extent of watershed about 13,384 ha is one of rivers flowing through Jakarta City that causes flood problem every years. Many effort has been done to reduce flood problem, among others is to build reservoir in watershed, but the effectiveness of reservoir is still questionable. A research aimed to analyze gap of reservoir capacity changes and its influence on hydrological response and to arrange the scenario of reservoir capacity change to improve hydrological response in Pesanggrahan Watershed was done using HEC-HMS Model. Reservoir capacity change scenarios applied to the actual rainfall condition and designed rainfall condition with a certain recurrence interval. The scenarios consist of: reservoir with the exsisting condition (scenario 1), increase depth of reservoir to 5 meters (scenario 2) and build 6 reservoirs on Pesanggrahan watershed (scenario 3). The model was calibrated using daily discharge data from the date of January $10^{\text {th }}$ to April 30 $0^{\text {th }}$ 2009. Model calibration result shows that model is quite accurate to predict peak discharge in Pesanggrahan Watershed with Nash-Sutcliffe efficiency value $=0.9817$ and $R^{2}=0.975$. Simulation results showed that the reservoir is effective in decreasing its local effect to peak discharge (reservoir area). The presence of reservoir with existing condition reduce only $6.38 \%$ of the peak run off in outlet Kebon jeruk, whereas building of 6 reservoir will reduce $24.6 \%$ of the peak run off in outlet Kebon jeruk.
\end{abstract}

Keywords : HEC-HMS Model, peak discharge, Reservoir capacity change

\begin{abstract}
ABSTRAK
Sungai Pesanggrahan dengan luas daerah tangkapan air sekitar 13,384 Ha merupakan salah satu sungai yang mengalir melalui Jakarta.yang sering menimbulkan banjir. Banyak usaha telah dilakukan untuk mengatasi masalah banjir ini, diantaranya adalah dengan membuat situ-situ (reservoir) di daerah alitan sungainya (DAS), tetapi sejauh ini efektifitas usaha tersebut masih dipertanyakan. Suatu penelitian yang bertujuan untuk menganalisa perubahan kapasitas situ/waduk dan pengaruhnya terhadap respon hidrologi serta menyusun skenario perubahan kapasitas situ untuk memperbaiki respon hidrologi di DAS Pasanggrahan dilakukan dengan menggunakan model HEC-HMS. Skenario perubahan kapasitas situ diterapkan dengan kondisi curah hujan aktual dan curah hujan rencana dengan periode ulang tertentu. Ada tiga (3) skenario yang diterapkan yaitu 1) kondisi situ seperti apa adanya saat ini, 2) pendalaman situ yang ada menjadi 5 meter, dan 3) membuat 6 situ baru di DAS Pasanggrahan. Model dikalibrasi menggunakan data debit harian yang diperoleh dari tanggal 10 Januari -30 April 2009. Hasil kalibrasi menunjukkan bahwa model akurat untuk memprediksi debik puncak sungai Pasanggrahan dengan koefisien Nash-Sutcliffe 0.9817 dan koefisien determinasi 0.975. Hasil simulasi 3 skenario menggunakan model HEC-HMS menunjukkan bahwa keberadaan situ cukup efektif dalam mengurangi debit puncak secara local. Keberadaan situ dengan kondisi saat ini menurunkan debit puncak di outlet Kebon Jeruk hanya sekitar 6.38\%, sementara pembuatan 6 situ baru mampu menurunkan debit puncak sebesar $24.6 \%$ di outlet yang sama.
\end{abstract}

Kata kunci : Debit puncak, Model HEC-HMS, perubahan kapasitas situ 


\section{PENDAHULUAN}

Sejalan dengan pertumbuhan penduduk di Jabodetabek, intensitas perubahan penggunaan lahan semakin tinggi yang seringkali tidak mengikuti konsep pengelolaan/penggunaan berdasarkan konservasi tanah dan air. Dampak yang sering muncul apabila pola pemanfaatan lahan tidak sesuai adalah terjadinya banjir. Permasalahan banjir bermula dari ketidakmampuan dari DAS menahan dan menyerap air sehingga terjadi aliran permukaan (runoff) yang berlebihan. Banjir akan terjadi apabila kapasitas alir sungai tidak dapat mengalirkan aliran permukaan, sehingga air akan meluap dan mengenangi daerah pemukiman penduduk. Salah satu sungai yang mempunyai daya tampung terbatas yaitu Sungai Pesanggrahan yang mengalir dari selatan wilayah Bogor dan memasuki wilayah DKI Jakarta.

Selain padatnya pemukiman penduduk dan pemanfaatan bantaran sungai, pengurangan rawa-rawa dan daerah-daerah cekungan yang ada di daerah hulu DAS Pesanggrahan merupakan penyebab meningkatnya limpasan air hujan sehingga terjadi banjir, yang akhir-akhir ini makin meningkat baik frekuensi maupun intensitasnya. Berbagai upaya telah dilakukan untuk mengatasi masalah banjir ini, salah satu diantaranya adalah dengan membuat situ. Secara teoritis, keberadaan situ akan menghambat aliran air sehingga jumlah limpasan dan banjir berkurang. Namun bagaimana efektifitas keberadaan situ dalam mengatasi masalah banjir seringkali masih dipertanyakan (Subandrio, 2006).

Berdasarkan latar belakang tersebut diperlukan pengkajian respon hidrologi terhadap adanya situ-situ dengan menggunakan model HEC - HMS (Hydrology Engineering Corps - Hydrology Modelling System). Kelebihan model ini adalah selain dapat mendeteksi limpasan (run off) pada setiap sub-DAS, juga mampu mengevaluasi struktur pengendali limpasan, yang dalam kajian ini berupa situ-situ (USACE, 2001). Model ini diharapkan dapat dijadikan acuan dalam perencanaan pengelolaan Daerah Aliran Sungai Pesanggrahan, khususnya untuk simulasi perubahan kapasitas situ dan penambahan situ-situ baru terhadap limpasan yang dihasilkan.

Tujuan dari penelitian ini adalah (1) Menganalisis perubahan kapasitas situ dan pengaruhnya terhadap respon hidrologi DAS Pesanggrahan menggunakan Model HECHMS dan (2) menyusun skenario perubahan kapasitas situ untuk memperbaiki respon hidrologi.

\section{METODOLOGI PENELITIAN}

Penelitian ini dilaksanakan di DAS Pesanggrahan. DAS Pesanggrahan memiliki luas 13,384 ha. Secara geografis daerah penelitian terletak pada $6^{\circ} 10^{\prime} 20^{\prime \prime}-6^{\circ} 33^{\prime}$ $50^{\prime \prime}$ Lintang Selatan dan $106^{\circ} 44^{\prime} 15^{\prime \prime}-106^{\circ} 48^{\prime} 05^{\prime \prime}$ Bujur Timur. Secara administratif sebagian berada di wilayah
Kabupaten Bogor Propinsi Jawa Barat dan sebagian berada di wilayah Propinsi DKI Jakarta (Gambar 1).

Penelitian dilakukan melalui beberapa tahapan untuk melihat respon hidrologi terhadap keberadaan situ di Daerah Aliran Sungai Pesanggrahan, antara lain: 1) pengumpulan data, 2) aplikasi model dan 3) simulasi model. Diagram alir penelitian disajikan pada Gambar 2

\section{Pengumpulan Data}

Data primer diperoleh melalui pengamatan di lapangan, meliputi: geometri sungai, parameter kekasaran saluran dan kondisi tanah pada beberapa jenis penggunaan lahan.

Data sekunder yang mencakup peta rupa bumi skala 1:25.000, peta satuan tanah semi detil skala 1:50.000, peta penutupan lahan tahun 2008 dengan Skala 1:25.000, peta DEM (Digital Elevation Model) dari Citra satelit Radar SRTM tahun 2004, data curah hujan dan data debit aliran dan data tinggi muka air sungai pesanggrahan dan data situ-situ yang ada di DAS pesanggrahan diperoleh dari berbagai instansi terkait.

\section{Aplikasi Model}

Aplikasi model HEC-HMS dilakukan melalui beberapa tahapan yaitu penyiapan data input, pengolahan data, kalibrasi model dan aplikasi model. Diagram alir penelitian dapat dilihat pada Gambar 2.

Program HEC-HMS terdiri dari tiga komponen model yaitu model basin, model meteorologi dan kontrol spesifikasi. Data yang digunakan dalam model basin adalah data biofisik DAS, data saluran sungai dan kapasitas tampungan situ, sedangkan data yang dibutuhkan dalam model meteorologi adalah data curah hujan DAS. Kontrol spesifikasi dalam model HEC-HMS adalah batasan kejadian pengamatan hidrologi.

\section{Simulasi Model HEC-HMS}

Simulasi Model dilakukan untuk mengetahui pengaruh situ terhadap respon hidrologi DAS Pesanggrahan, sehingga dapat diketahui peningkatan atau penurunan debit banjir akibat pe

rubahan kapasitas tampungan situ. Simulasi ini dilakukan terhadap data curah hujan rancangan terhadap berbagai kapasitas tampungan situ. Simulasi model dilakukan berdasarkan skenario sebagai berikut :

S-1. a. Kondisi saat ini dengan 2 situ (Situ Pamulang dan Situ Ciledug).

b. Kondisi saat Situ Gintung masih ada.

S-2. Dilakukan pengerukan situ dengan kedalaman 5 meter.

S-3. Membangun 6 situ baru yang karakteristiknya sama dengan Situ Ciledug sehingga jumlah situ di DAS Pesanggrahan menjadi 9 situ.

S-4. Menutup situ-situ yang ada di DAS Pesanggrahan. 


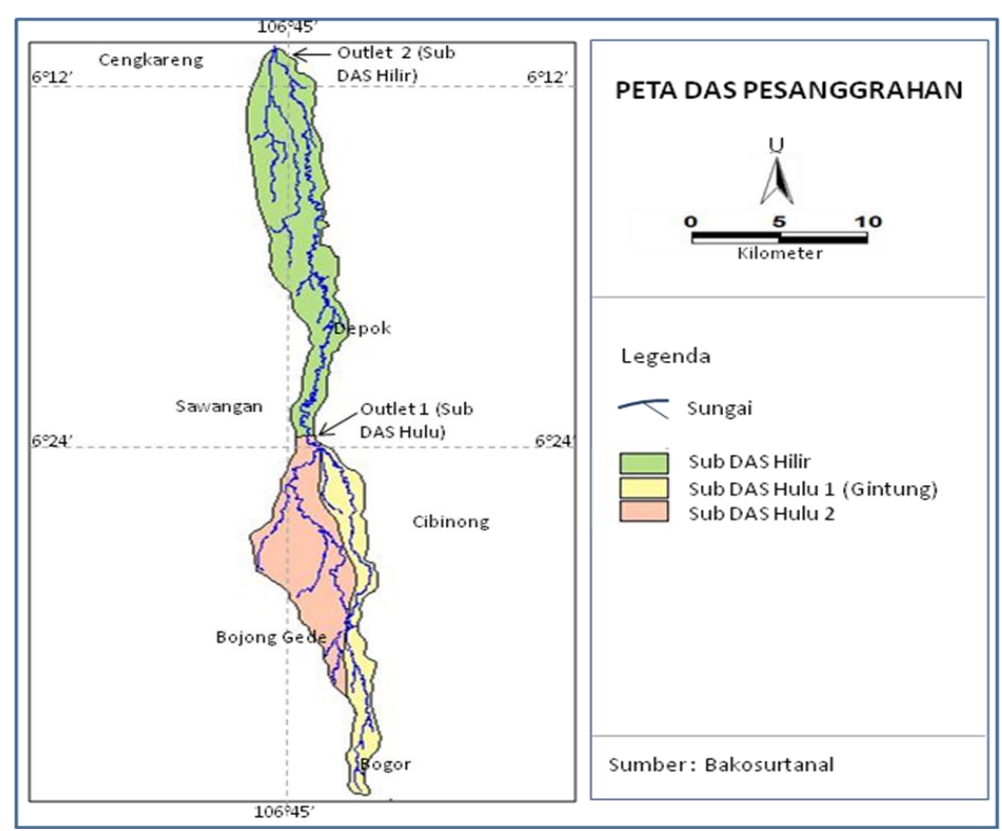

Gambar 1. Lokasi penelitian

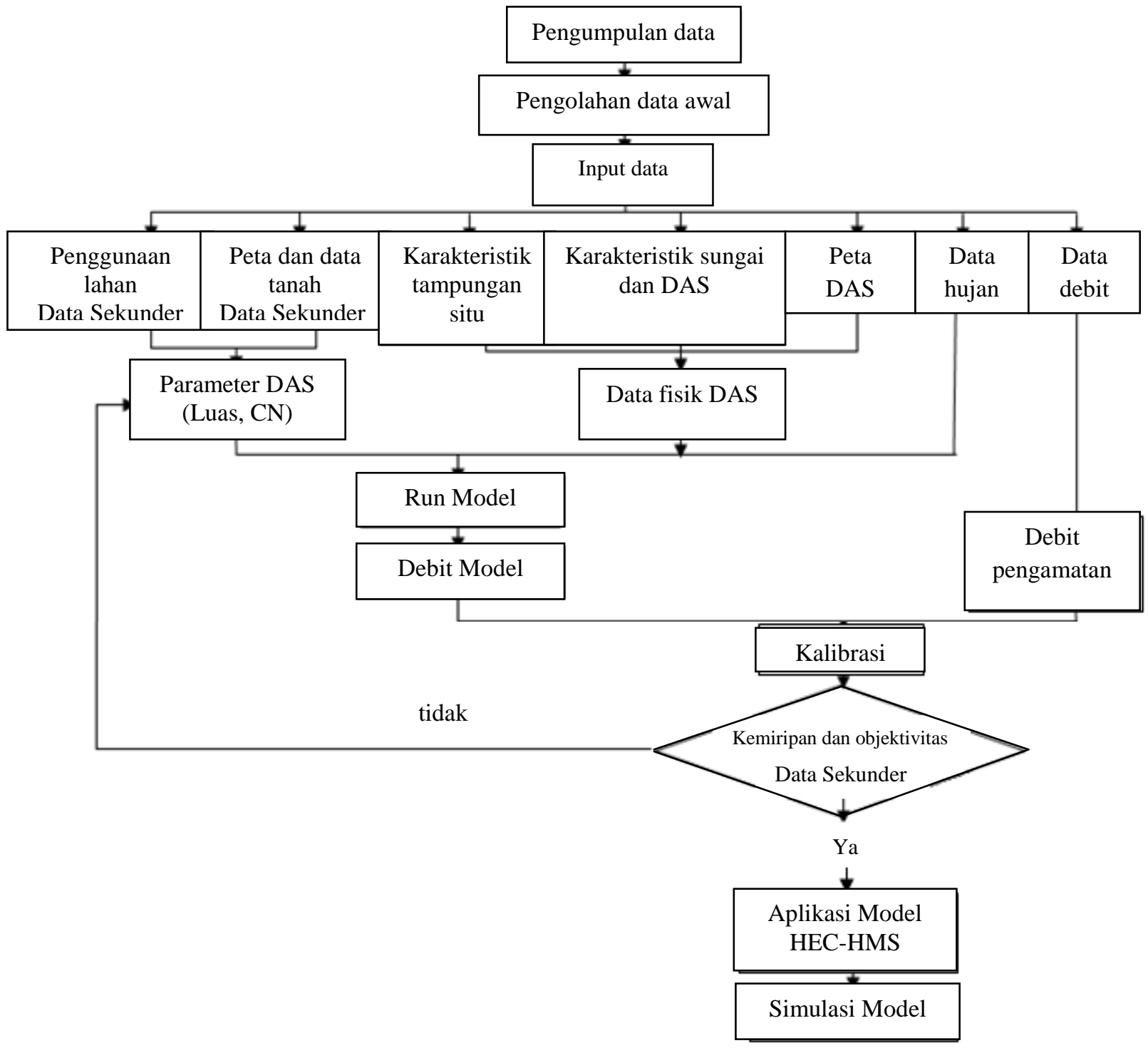

Gambar 2. Diagram alir penelitian 


\section{HASIL DAN PEMBAHASAN}

\section{Analisis Curah Hujan Rancangan}

Analisis curah hujan harian maksimum dalam setahun dari data tahun 1973-2002 mendapatkan bahwa nilai ratarata curah hujan harian maksimum di tiga (3) stasiun yaitu, Stasiun Cengkareng, Sawangan dan Cibinong berturut-turut adalah sebesar $109 \mathrm{~mm}, 113 \mathrm{~mm}$, dan $85.0 \mathrm{~mm}$. Nilai ratarata ke-3 stasiun dengan metode poligon Thiessen adalah sebesar $109 \mathrm{~mm}$. Curah hujan harian maksimum tertinggi sebesar $176 \mathrm{~mm}$ terjadi pada tahun 1984 dan curah hujan harian maksimum yang terendah sebesar $64.6 \mathrm{~mm}$ terjadi pada tahun 1982. Hasil analisis peluang curah hujan harian maksimum pada berbagai periode ulang disajikan pada Tabel 1.

Tabel 1. Curah hujan harian maksimum untuk berbagai periode ulang

\begin{tabular}{cc}
\hline $\begin{array}{c}\text { Periode Ulang } \\
\text { T (Tahun) }\end{array}$ & $\begin{array}{c}\text { Curah hujan harian maksimum } \\
(\mathrm{mm})\end{array}$ \\
\hline 2 & 106 \\
5 & 132 \\
10 & 148 \\
25 & 167 \\
50 & 181 \\
\hline
\end{tabular}

Sumber : Hasil perhitungan

\section{Kalibrasi Model}

Kalibrasi model dilakukan dengan membandingkan debit hasil perhitungan model dengan debit hasil pengukuran pada SPAS Kebon Jeruk (Outlet Sub-DAS Hilir). Kalibrasi dilakukan menggunakan data hujan dan debit air tahun 2009 untuk periode harian yaitu sejak tanggal 10 Januari sampai 30 April 2009. Kalibrasi dilakukan berdasarkan pada hasil hidrograf dimana nilai debit hasil simulasi tinggi pada beberapa titik dan rendah pada titik yang lain. Berdasarkan keadaan tersebut maka dilakukan penyesuaian terhadap beberapa parameter. Hasil kalibrasi menunjukkan bahwa nilai efisiensi Nash-Sutcliffe (NS) sebesar 0.9817 dan $\mathrm{R}^{2}$ sebesar 0.975. Hal ini berarti bahwa aplikasi model untuk DAS Pesanggrahan sangat memuaskan.

Uji dengan metode T-test antara debit puncak (Qp) hasil prediksi model dengan debit puncak terukur dan antara volume aliran hasil prediksi dengan volume aliran terukur, diperoleh nilai $\mathrm{T}$ berturut-turut adalah 0.332 untuk debit puncak dan 0.418 untuk aliran permukaan. Nilai ini masih lebih rendah dari nilai $\mathrm{T}(\alpha=0.05)$ yaitu sebesar 1.06 dan 0.87. Tabel 2 dan Gambar 3 memperlihatkan hasil perbandingan antara pengukuran dengan model HEC-HMS yang tidak berbeda nyata dan menunjukkan adanya korelasi yang baik.

Simulasi model hidrologi HEC-HMS dengan menggunakan curah hujan rancangan untuk periode ulang tertentu dengan kondisi situ pada DAS saat ini (terdapat 2 buah situ saat ini yaitu Situ Pamulang dan Situ Ciledug) kemudian dilakukan. Hasil simulasi berupa debit rancangan pada outlet Kebon Jeruk disajikan pada Tabel 3. Simulasi model HEC-HMS selanjutnya yang dilakukan untuk melihat pengaruh perubahan kapasitas situ terhadap debit aliran permukaan dilakukan dengan asumsi bahwa semua parameter masukan model adalah tetap kecuali parameter curah hujan dan jumlah atau kapasitas tampungan situ.

Tabel 3. Curah hujan dan debit rancangan DAS Pesanggrahan dengan periode ulang tertentu

\begin{tabular}{ccc}
\hline $\begin{array}{c}\text { Periode Ulang } \\
(\text { Tahun })\end{array}$ & $\begin{array}{c}\text { Curah Hujan Rancangan } \\
(\mathrm{mm})\end{array}$ & Debit $\left(\mathrm{m}^{3} \mathrm{det}^{-1}\right)$ \\
\hline 2 & 106 & 116 \\
5 & 132 & 145 \\
10 & 148 & 165 \\
25 & 167 & 191 \\
50 & 181 & 210 \\
\hline
\end{tabular}

Sumber : Hasil simulasi hidrologi

Tabel 2. Perbandingan hasil simulasi model hidrologi HEC-HMS dengan hasil pengukuran

\begin{tabular}{cccccc}
\hline Tanggal & Curah hujan & \multicolumn{2}{c}{ Debit puncak (Qp) $\mathrm{m}^{3} \mathrm{det}^{-1}$} & \multicolumn{2}{c}{ Volume $\left(10^{3} \mathrm{~m}^{3}\right)$} \\
& $(\mathrm{mm})$ & Model & Pengukuran & Model & Pengukuran \\
\hline 10 - 23 Januari 2009 & 12.8 & 50.4 & 49.6 & 36,962 & 35,377 \\
28 Jan - 10 Feb 2009 & 14.8 & 49.9 & 50.1 & 22,786 & 23,504 \\
15 - 28 Februari 2009 & 9.58 & 32.9 & 33.5 & 21,167 & 21,403 \\
01 - 14 Maret 2009 & 13.9 & 50.4 & 49.6 & 21,627 & 22,958 \\
17 - 30 Maret 2009 & 12.4 & 43.9 & 43.6 & 19,052 & 19,844 \\
02 - 15 April 2009 & 13.2 & 49.5 & 50.1 & 19,715 & 19,453 \\
17 - 30 April 2009 & 12.1 & 34.3 & 34.4 & 17,388 & 17,388 \\
\hline
\end{tabular}



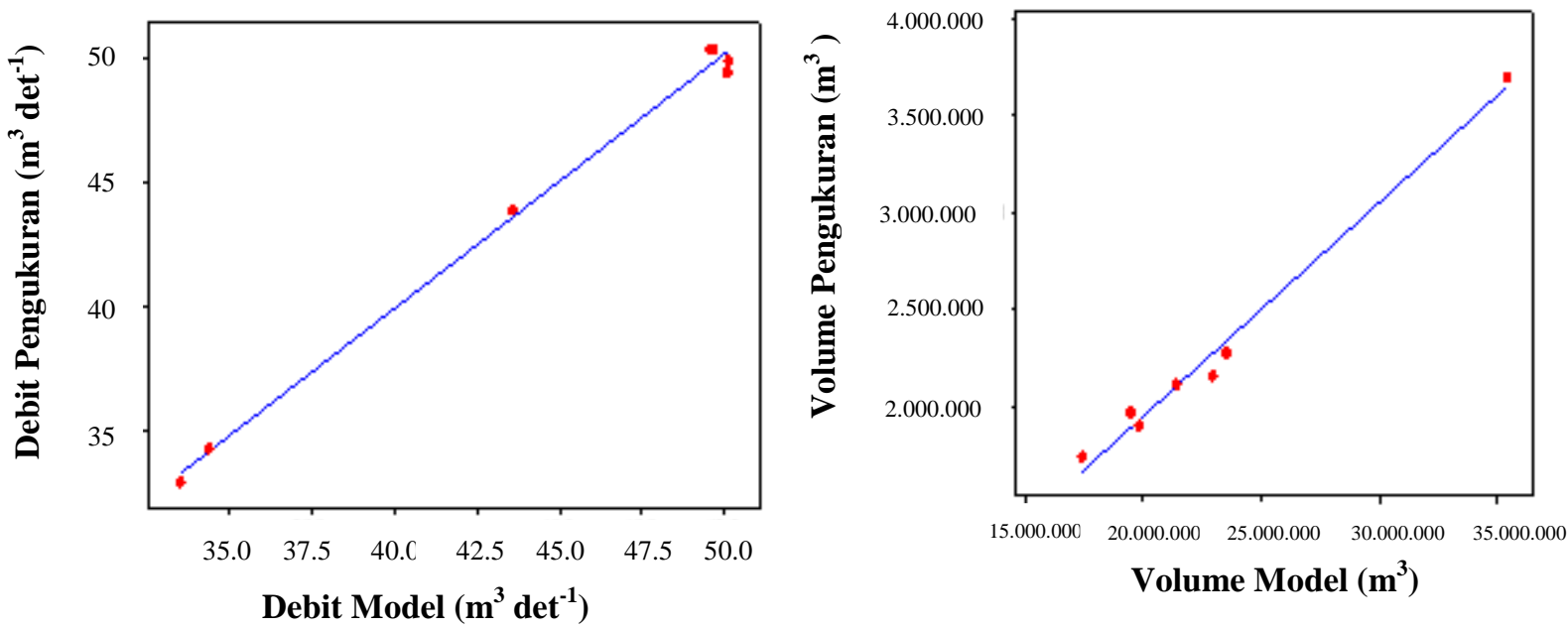

Gambar 3. Perbandingan sebaran data hasil simulasi model dan pengukuran untuk debit dan volume aliran

Analisis perubahan kapasitas situ terhadap respon hidrologi

Untuk melihat pengaruh perubahan kapasitas situ terhadap respon hidrologi, simulasi dilakukan terhadap individu situ. Situ yang dipilih adalah Situ Gintung sebagai salah satu situ yang ada di DAS Pesanggrahan. Situ Gintung berada di Sub DAS hulu Pesanggrahan, dengan luas Sub DAS 6,682 ha. Saat ini Situ Gintung masih dalam tahap perbaikan secara fisik setelah tanggulnya jebol tahun 2009. Situ Gintung mempunyai luas genangan air sebasar 29.3 ha dan merupakan salah satu situ terbesar di DAS Pesanggrahan, kedalaman maksimum $6.50 \mathrm{~m}$, kapasitas tampung air sebesar $801,940 \mathrm{~m}^{3}$ dengan tampungan tetap $80.1 \%$ (DPU, 2007).

Simulasi dilakukan dengan menggunakan data curah hujan aktual sebesar $25 \mathrm{~mm}$ pada Sub DAS hulu DAS Pesanggrahan yang terdapat Situ Gintung. Hasil simulasi menunjukkan bahwa adanya Situ Gintung menurunkan debit puncak hidrograf (Qp) dari $13.1 \mathrm{~m}^{3} \mathrm{det}^{-1}$ menjadi 8.53 $\mathrm{m}^{3} \mathrm{det}^{-1}$ atau sekitar $34.7 \%$ dan memperpanjang waktu mencapai puncak hidrograf dari 5 jam menjadi 7 jam. Jika dilakukan simulasi dengan luas Situ Gintung diperkecil menjadi 15.9 ha, kedalaman maksimum $4.50 \mathrm{~m}$ dan tampungan tetap menjadi $77.9 \%$, maka debit puncaknya meningkat menjadi $11.4 \mathrm{~m}^{3} \operatorname{det}^{-1}$ dan mempercepat waktu puncak hidrograf menjadi 6 jam. Bila Situ Gintung diperdalam menjadi 11.5 meter dengan luas permukaan air tetap dan penambahan volume tampungan air sebesar $754,760 \mathrm{~m}^{3}$, maka debit puncak aliran pada outlet akan turun menjadi $8.12 \mathrm{~m}^{3} \mathrm{det}^{-1}$ dan waktu mencapai puncak hidrograf akan makin lama menjadi 7 jam. Hasil simulasi secara lengkap disajikan pada Tabel 4 dan Gambar 4.

Luas situ mempengaruhi persentase penurunan debit puncak aliran. Makin luas ukuran situ maka persentase penurunan debit puncak aliran semakin besar, sedangkan semakin kecil ukuran situ maka kontribusi penurunan debit aliran semakin kecil. Menurut Legowo et al. (2009) waduk (situ) pengendali banjir adalah bangunan yang berfungsi menahan semua atau sebagian air banjir dalam tampunganya dan mengalirkan sesuai dengan kapasitas sungai. Waduk (situ) yang lebih besar mampu untuk menampung seluruh volume banjir, yang dapat disimpan untuk kegunaan di masa yang akan datang secara terkendali. Waduk (situ) yang lebih kecil hanya bisa menampung sebagian volume banjir, tetapi dapat meredam puncak inflow, sehingga terjadi pengurangan outflow melewati spillway.

Hasil simulasi menunjukkan bahwa penurunan debit puncak hidrograf relatif kecil setelah situ diperdalam. Hal ini disebabkan karena total luas permukaan air situ tetap bila dibandingkan dengan luas SubDAS Hilir DAS Pesanggrahan (0.24\%). Pendalaman situ hanya meningkatkan daya tampung situ yang apabila dibandingkan dengan volume airan dari daerah tangkapan diatasnya sangat kecil.

\section{Respon hidrologi pada beberapa skenario perubahan kapasitas situ}

Untuk melihat bagaimana pengaruh perubahan kapasitas situ terhadap respon hidrologi (debit aliran), simulasi model HEC-HMS dilakukan terhadap DAS Pesanggrahan secara keselruhan dengan total luas DAS sebesar 13,384 ha. Saat ini di DAS Pesanggrahan terdapat 2 situ yaitu Situ Pamulang dan Situ Ciledug. Hasil simulasi berdasarkan skenario perubahan kapasitas situ pada curah hujan rancangan 2, 5, 10, 25 dan 50 tahun menunjukkan penurunan debit puncak aliran permukaan permukaan pada DAS Pesanggrahan. Dalam simulasi ini, waktu mencapai puncak aliran dibuat tetap untuk semua periode ulang. Hasil simulasi model disajikan pada Tabel 5. 
Tabel 4. Hasil simulasi perubahan berbagai kapasitas Situ Gintung

\begin{tabular}{lccc}
\hline \multicolumn{1}{c}{ Simulasi } & $\mathrm{Qp}\left(\mathrm{m}^{3} \mathrm{det}^{-1}\right)$ & $\mathrm{Tp}(\mathrm{jam})$ & $*(\%)$ \\
\hline Tanpa situ & 13.1 & 5 & \\
Situ Gintung & 8.53 & 7 & 34.7 \\
Situ Gintung diperkecil & 11.4 & 6 & 12.9 \\
Situ Gintung diperdalam 5 m & 8.12 & 7 & 37.8 \\
\hline Keterangan : * (\% penurunan) & &
\end{tabular}

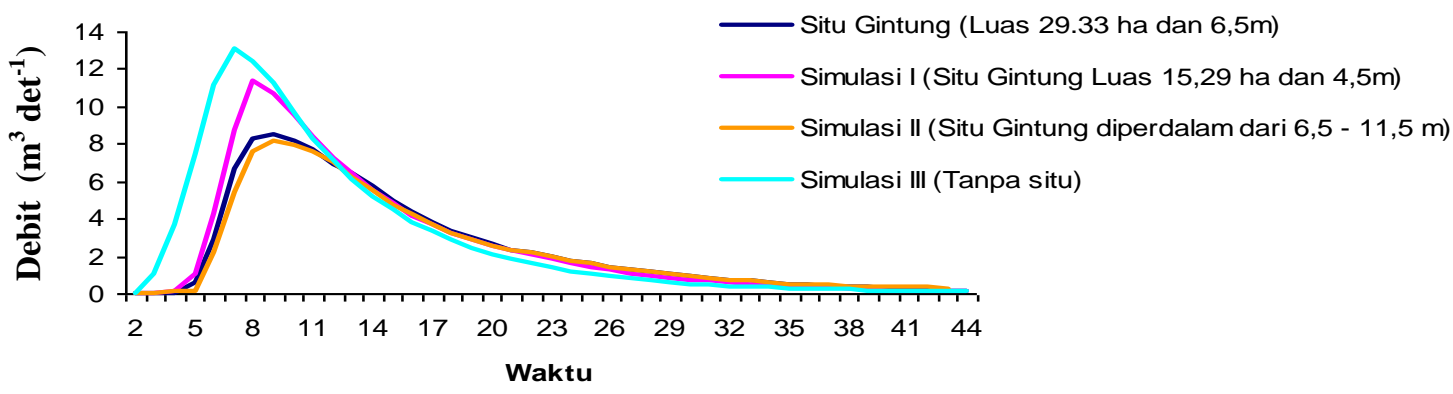

Gambar 4. Hidrograf simulasi pada outlet Situ Gintung

Tabel 5. Hasil simulasi perubahan kapasitas situ pada berbagai kondisi curah hujan rancangan

\begin{tabular}{|c|c|c|c|c|c|c|c|c|c|c|c|c|c|c|}
\hline \multirow{2}{*}{$\begin{array}{c}\text { Periode } \\
\text { ulang }\end{array}$} & \multicolumn{3}{|c|}{ S-1a: Situ saat ini } & \multicolumn{3}{|c|}{ S-1b:Jika ada St. Gintung } & \multicolumn{3}{|c|}{ S-2: Situ diperdalam $5 \mathrm{~m}$} & \multicolumn{3}{|c|}{ S-3:Dibangun 6 situ } & \multicolumn{2}{|c|}{ S-4 :Tanpa situ } \\
\hline & $\begin{array}{c}\text { Qp } \\
\mathrm{m}^{3} \mathrm{~S}^{-1}\end{array}$ & $\begin{array}{c}\text { Tp } \\
\text { jam }\end{array}$ & $*(\%)$ & $\begin{array}{c}\text { Qp } \\
\mathrm{m}^{3} \mathrm{~S}^{-1}\end{array}$ & $\begin{array}{c}\text { Tp } \\
\text { Jam }\end{array}$ & $*(\%)$ & $\begin{array}{c}\mathrm{Qp} \\
\mathrm{m}^{3} \mathrm{~S}^{-1}\end{array}$ & $\begin{array}{c}\text { Tp } \\
\text { jam }\end{array}$ & $*(\%)$ & $\begin{array}{c}\text { Qp } \\
\mathrm{m}^{3} \mathrm{~S}^{-1}\end{array}$ & $\begin{array}{c}\text { Tp } \\
\text { jam }\end{array}$ & $*(\%)$ & $\begin{array}{c}\mathrm{Qp} \\
\mathrm{m}^{3} \mathrm{~S}^{-1}\end{array}$ & $\begin{array}{r}\text { Tp } \\
\text { jam }\end{array}$ \\
\hline 2 thn & 116 & 6 & 6.30 & 112 & 6 & 9.46 & 109 & 6 & 11.5 & 93.4 & 7 & 24.5 & 124 & 6 \\
\hline 5 thn & 145 & 6 & 6.50 & 140 & 6 & 9.60 & 137 & 6 & 11.9 & 117 & 7 & 24.7 & 155 & 6 \\
\hline 10 thn & 165 & 6 & 6.30 & 160 & 6 & 9.31 & 155 & 6 & 11.9 & 133 & 7 & 24.5 & 176 & 6 \\
\hline 25 thn & 192 & 6 & 6.41 & 185 & 6 & 9.52 & 181 & 6 & 11.8 & 155 & 7 & 24.5 & 205 & 6 \\
\hline 50 thn & 211 & 6 & 6.38 & 204 & 6 & 9.46 & 199 & 6 & 11.9 & 170 & 7 & 24.6 & 226 & 6 \\
\hline \multicolumn{2}{|c|}{$\%$ Rata-rata } & & 6.38 & & & 9.47 & & & 11.8 & & & 24.6 & & \\
\hline
\end{tabular}

Keterangan : * persentase penurunan terhadap debit aliran tanpa situ ; S-1 s/d S-4 : Skenario 1 s/d skenario 4

Sumber : Hasil simulasi hidrologi

DAS Pesanggrahan dengan keberadaan situ saat ini mampu menurunkan debit puncak aliran permukaan ratarata sebesar $6.38 \%$ dibandingkan kondisi tanpa situ, dengan waktu puncak hidrograf 6 jam. Sementara DAS Pesanggrahan ketika masih ada Situ Gintung debit puncak aliran permukaannya menurun rata-rata sebesar $9.47 \%$ dibandingkan kondisi tanpa situ, dengan waktu puncak hidrograf 6 jam. Penurunan debit puncak hidrograf yang relatif kecil tersebut disebabkan karena total luas permukaan air situ sangat kecil bila dibandingkan dengan luas DAS Pesanggrahan (0.59\%). Data karateristik situ-situ yang ada di DAS Pesanggrahan disajikan pada Tabel 6.
Tabel 6. Karakteristik Situ di DAS Pesanggrahan

\begin{tabular}{ccccccc}
\hline No & Situ & $\begin{array}{c}\text { Luas } \\
\text { (ha) }\end{array}$ & $\begin{array}{c}\text { Kapasitas } \\
\left(\mathrm{m}^{3}\right)\end{array}$ & $\begin{array}{c}\text { Kedalaman } \\
\text { maksimum } \\
(\mathrm{m})\end{array}$ & $\begin{array}{c}\text { Tampungan } \\
\text { Tetap } \\
(\%)\end{array}$ & $\begin{array}{c}\text { TA Situ } \\
(\text { ha) }\end{array}$ \\
\hline 1 & Pamulang & 28.5 & 960,840 & 7 & 78.4 & 329 \\
2 & Ciledug & 20.9 & 534,255 & 5 & 44.9 & 232 \\
3 & Gintung & 29.3 & 801,940 & 6.5 & 80.1 & 357 \\
\hline
\end{tabular}

Sumber : hasil perhitungan dan data sekunder

Peningkatan kapasitas situ di DAS Pesanggrahan dengan meningkatkan kedalaman situ menjadi 5 meter, akan menurunkan debit puncak sebesar $11.8 \%$ dibandingkan kondisi tanpa situ, dengan waktu puncak hidrograf 6 jam. Walaupun situ sudah bertambah kapasitasnya dengan diperdalam tetapi penurunan debit puncak hidrograf masih relatif kecil, hal ini disebabkan oleh total luas daerah tangkapan air situ kecil, yaitu sebesar 6.85\% dari DAS Pesanggrahan sehingga walaupun situ diperdalam hanya memiliki pengaruh yang kecil. 
Jika kondisi situ saat ini ditambah dengan membangun 6 buah situ baru maka debit puncak alirannya menurun sebesar $24.6 \%$ dibandingkan kondisi tanpa situ, dengan waktu puncak hidrograf diperpanjang dari 6 jam menjadi 7 jam. Hasil simulasi menunjukkan dengan menambah 6 buah situ baru telah menurunkan debit puncak aliran yang berarti, hal ini disebabkan luas total keenam situ sebesar 125 ha, dengan kapasitas tampung air sebesar 3,205,530 m dan luas daerah tangkapan air situ menjadi 1,392 ha, sehingga kapasitas tampung air situ DAS Pesanggrahan menjadi 5,502,565 $\mathrm{m}^{3}$, luas permukaan air situ menjadi 204 ha dan luas daerah tangkapan air situ menjadi 2,310 ha.

\section{Evaluasi penerapan skenario rancangan model terhadap respon hidrologi pada DAS Pesanggrahan}

Berdasarkan hasil simulasi model diperoleh perbedaan pengaruh situ terhadap respon hidrologi, dimana pengaruh situ secara individu memberikan kontribusi persentase penurunan debit puncak aliran lebih besar dibandingkan kondisi situ-situ pada DAS secara keseluruhan. Hal ini disebabkan pengaruh situ secara individu terjadi pada suatu SubDAS yang luasannya lebih kecil dibandingkan luas DAS keseluruhan. Dengan demikian adanya situ hanya efektif dalam mengendalikan debit puncak aliran yang bersifat lokal (daerah SubDAS).

Banjir secara rutin terjadi di daerah yang dilalui Sungai Pesanggrahan dari tahun ke tahun dan berlangsung dengan intensitas yang beragam. Menurut Subandrio et al. (2009) Sungai Pesanggrahan saat ini memiliki kapasitas alir penampang terbesar $110 \mathrm{~m}^{3} \operatorname{det}^{-1}$ dan penampang terkecil sebesar $75 \mathrm{~m}^{3} \operatorname{det}^{-1}$. Hasil simulasi model HEC-HMS menunjukkan bahwa Sungai Pesanggrahan dengan keberadaan situ saat ini termasuk adanya Situ Gintung bahkan tidak mampu mengalirkan debit aliran rancangan 2 tahunan $\left(116 \mathrm{~m}^{3} \mathrm{det}^{-1}\right)$. Artinya frekuensi terjadinya banjir sangat besar. Tetapi jika skenario S-2 dan S-3 diterapkan pada kondisi curah hujan rancangan 2 tahunan maka debit puncak alirannya menurun menjadi $109 \mathrm{~m}^{3} \operatorname{det}^{-1}$ dan 93.4 $\mathrm{m}^{3} \operatorname{det}^{-1}$. Angka ini lebih rendah dari kapasitas alir penampang sungai Pesanggrahan. Hal ini berarti bahwa skenario S-2 dan S-3 mampu mengatasi debit banjir Sungai Pesanggrahan dengan periode ulang 2 tahunan. Sebagai perbandingan, kejadian banjir Sungai Pesanggrahan pada tahun 2006 dengan besar curah hujan 94 menghasilkan debit puncak aliran di outlet Kebon Jeruk sebesar 125 $\mathrm{m}^{3} \operatorname{det}^{-1}$, dengan genangan banjir seluas 27 ha. Walaupun dengan curah hujan yang lebih kecil yaitu $87 \mathrm{~mm}$ pada tahun 2009 debit puncak yang mengalir di outlet Kebon Jeruk sudah mendekati kejadian tahun 2006 yaitu sebesar $116 \mathrm{~m}^{3} \operatorname{det}^{-1}$ dengan luas genangan banjir sebesar 8 ha.

Hasil simulasi dengan membangun 6 buah situ baru (S-3) di DAS Pesanggrahan merupakan skenario rancangan terbaik sebab dapat menurunkan debit puncak aliran sebesar $24.4 \%$ bahkan mampu mengatasi debit banjir setara dengan kejadian banjir tahun 2006 dan 2009. Akan tetapi, penerapan skenario rancangan S-3 belum bisa mengatasi permasalahan banjir pada DAS Pesanggrahan untuk kejadian banjir di atas curah hujan rancangan 2 tahunan.
Sebagai contoh kejadian banjir besar yang pernah terjadi pada tahun 2007 dengan besar curah hujan $266 \mathrm{~mm}$, menghasilkan debit aliran di outlet Kebon Jeruk sebesar $305 \mathrm{~m}^{3} \mathrm{det}^{-1}$ yang mengakibatkan genangan banjir seluas 92 ha selama 2 - 3 hari.

\section{SIMPULAN}

Hasil simulasi dengan adanya situ-situ di DAS Pesanggrahan berdasarkan skenario rancangan yang disusun memberikan respon terhadap debit aliran permukaan. Situ yang berukuran besar lebih efektif menurunkan debit puncak aliran dibandingkan dengan situ yang berukuran kecil. Namun adanya situ hanya efektif dalam menurunkan debit banjir yang bersifat lokal (daerah SubDAS).

Situ yang ada di DAS Pesanggrahan mempunyai total luas permukaan air sebesar 49.1 ha dengan kapasitas tampung air sebesar 1,495,100 $\mathrm{m}^{3}$ dan daerah tangkapan air situ sebesar 561 ha. Kapasitas situ ini hanya mampu menurunkan debit aliran puncak sebesar $6.38 \%$ pada Stasiun pengamatan Kebon Jeruk.

Penyusunan skenario dengan membangun 6 buah situ baru di DAS Pesanggrahan mampu menurunkan debit puncak aliran sebesar $24.4 \%$ dan memperpanjang waktu puncak hidrograf 1 jam lebih lama dibanding kondisi situ saat ini. Akan tetapi perubahan kapasitas situ yang didapatkan dengan membangun 6 buah situ baru hanya dapat menaggulangi banjir akibat hujan rancangan dengan periode ulang $\leq 2$ tahunan. Banjir yang terjadi akibat curah hujan rancangan $>2$ tahunan belum dapat diatasi.

\section{DAFTAR PUSTAKA}

[DPU] Departemen Pekerjaan Umum. 2007. Kajian Potensi Sungai/Jaringan Irigasi Kali Angke/ Pesanggrahan. Dinas Pekerjaan Umum. Departemen Pekerjaan Umum, Jakarta.

Legowo, S. dan S. Teddy. 2003. Waduk Resapan sebagai Alternatif Pengendalian Banjir dan Kekeringan. Fakultas Teknik Sipil \& Lingkungan Institut Teknologi Bandung, Bandung.

Subandrio, P., I. Suprayogi, Kuswaya dan D. Legono. 2006. Pengendalian Banjir Kali Pesanggrahan Berwawasan Terpadu dan Berkelanjutan. Hasil Seminar HATHI Cabang Jakarta.

2009. Rehabilitasi Situ-situ Kawasan Jabodetabek. Balai Besar Wilayah Sungai Ciliwung-Cisadane, Jakarta.

[USACE] US Army Corp of Engineers. 2001. HEC_HMS River Analysis System: User's Manual Hydrologyic Engineering Center. Davis, CA, USA. 